Article

\title{
Thalhammerite, $\mathrm{Pd}_{9} \mathrm{Ag}_{2} \mathrm{Bi}_{2} \mathrm{~S}_{4}$, a New Mineral from the Talnakh and Oktyabrsk Deposits, Noril'sk Region, Russia
}

\author{
Anna Vymazalová ${ }^{1, *}$, František Laufek ${ }^{1}$, Sergey F. Sluzhenikin ${ }^{2}$, Vladimir V. Kozlov ${ }^{3}$, \\ Chris J. Stanley ${ }^{4}$, Jakub Plášil ${ }^{5}$, Federica Zaccarini ${ }^{6}$, Giorgio Garuti ${ }^{6}$ and Ronald Bakker ${ }^{6}$ \\ 1 Czech Geological Survey, Geologická 6, 15200 Prague 5, Czech Republic; frantisek.laufek@geology.cz \\ 2 Institute of Geology of Ore Deposits, Mineralogy, Petrography and Geochemistry RAS, \\ Staromonetnyi per. 12, Moscow 119017, Russia; sluzh@igem.ru \\ 3 Oxford Instruments (Moscow Office), 26 Denisovskii Pereulok, Moscow 105005, Russia; v.kozlov@oxinst.ru \\ 4 Department of Earth Sciences, Natural History Museum, London SW7 5BD, UK; c.stanley@nhm.ac.uk \\ 5 Institute of Physics, AS CR v.v.i. Na Slovance 2, 18221 Prague 8, Czech Republic; plasil@fzu.cz \\ 6 Department of Applied Geosciences and Geophysics, University of Leoben, Peter Tunner Str. 5, \\ A 8700 Leoben, Austria; federica.zaccarini@unileoben.ac.at (F.Z.); giorgio.garuti1945@gmail.com (G.G.); \\ ronald.bakker@unileoben.ac.at (R.B.) \\ * Correspondence: anna.vymazalova@geology.cz; Tel.: +420-251-085-228
}

Received: 19 July 2018; Accepted: 3 August 2018; Published: 8 August 2018

\begin{abstract}
Thalhammerite, $\mathrm{Pd}_{9} \mathrm{Ag}_{2} \mathrm{Bi}_{2} \mathrm{~S}_{4}$, is a new sulphide discovered in galena-pyrite-chalcopyrite and millerite-bornite-chalcopyrite vein-disseminated ores from the Komsomolsky mine of the Talnakh and Oktyabrsk deposits, Noril'sk region, Russia. It forms tiny inclusions (from a few $\mu \mathrm{m}$ up to about 40-50 $\mu \mathrm{m}$ ) intergrown in galena, chalcopyrite, and also in bornite. Thalhammerite is brittle and has a metallic lustre. In plane-polarized light, thalhammerite is light yellow with weak bireflectance, weak pleochroism, in shades of slightly yellowish brown and weak anisotropy; it exhibits no internal reflections. Reflectance values of thalhammerite in air $\left(\mathrm{R}_{1}, \mathrm{R}_{2}\right.$ in \%) are: $41.9 / 43.0$ at $470 \mathrm{~nm}, 43.9 / 45.1$ at $546 \mathrm{~nm}, 44.9 / 46.1$ at $589 \mathrm{~nm}$, and $46.3 / 47.5$ at $650 \mathrm{~nm}$. Three spot analyses of thalhammerite give an average composition: $\mathrm{Pd}$ 52.61, Bi 22.21, Pb 3.92, $\mathrm{Ag}$ 14.37, S 7.69, and Se 0.10, total $100.90 \mathrm{wt} \%$, corresponding to the empirical formula $\mathrm{Pd}_{8.46} \mathrm{Ag}_{2.28}\left(\mathrm{Bi}_{1.82} \mathrm{~Pb}_{0.32}\right)_{\Sigma 2.14}\left(\mathrm{~S}_{4.10} \mathrm{Se}_{0.02}\right)_{\Sigma 4.12}$ based on 17 atoms; the average of five analyses on synthetic thalhammerite is: $\mathrm{Pd} 55.10, \mathrm{Bi} 24.99, \mathrm{Ag} \mathrm{12.75}$, and $\mathrm{S} 7.46$, total $100.30 \mathrm{wt} \%$, corresponding to $\mathrm{Pd}_{8.91} \mathrm{Ag}_{2.03} \mathrm{Bi}_{2.06} \mathrm{~S}_{4.00}$. The density, calculated on the basis of the empirical formula, is $9.72 \mathrm{~g} / \mathrm{cm}^{3}$. The mineral is tetragonal, space group $I 4 / \mathrm{mmm}$, with a 8.0266(2), c 9.1531(2) $\AA, V$ 589.70(2) $\AA^{3}$ and $Z=2$. The crystal structure was solved and refined from the single-crystal X-ray-diffraction data of synthetic $\mathrm{Pd}_{9} \mathrm{Ag}_{2} \mathrm{Bi}_{2} \mathrm{~S}_{4}$. Thalhammerite has no exact structural analogues known in the mineral system; chemically, it is close to coldwellite $\left(\mathrm{Pd}_{3} \mathrm{Ag}_{2} \mathrm{~S}\right)$ and kravtsovite $\left(\mathrm{PdAg}_{2} \mathrm{~S}\right)$. The strongest lines in the $\mathrm{X}$-ray powder diffraction pattern of synthetic thalhammerite $[d$ in $\AA(I)(h k l)]$ are: 3.3428(24)(211), 2.8393(46)(220), 2.5685(21)(301), 2.4122(100)(222), 2.3245(61)(123), 2.2873(48)(004), 2.2201(29)(132), 2.0072(40)(400), 1.7481(23)(332), and 1.5085(30)(404). The mineral honours Associate Professor Oskar Thalhammer of the University of Leoben, Austria.
\end{abstract}

Keywords: thalhammerite; platinum-group mineral; $\mathrm{Pd}_{9} \mathrm{Ag}_{2} \mathrm{Bi}_{2} \mathrm{~S}_{4}$ phase; reflectance data; $\mathrm{X}$-ray-diffraction data; crystal structure; Komsomolsky mine; Talnakh deposit; Noril'sk region; Russia

\section{Introduction}

Thalhammerite, ideally $\mathrm{Pd}_{9} \mathrm{Ag}_{2} \mathrm{Bi}_{2} \mathrm{~S}_{4}$, was observed in the same holotype specimen as kravtsovite, $\mathrm{PdAg}_{2} \mathrm{~S}$ [1], and vymazalováite, $\mathrm{Pd}_{3} \mathrm{Bi}_{2} \mathrm{~S}_{2}$ [2]. The type sample (polished section) comes from 
vein-disseminated pyrite-chalcopyrite-galena ore from the Komsomolsky mine in the Talnakh deposit of the Noril'sk district, Russia. The sample was found at coordinates: $69^{\circ} 30^{\prime} 20^{\prime \prime} \mathrm{N}$ and $88^{\circ} 27^{\prime} 17^{\prime \prime}$ E. The mineralization is characterized by lack of Ni minerals and high galena content and Pt-Pd-Ag bearing minerals in an association of pyrite and chalcopyrite. The host rocks of pyrite-chalcopyrite-galena ore are diopside-hydrogrosssular-serpentine metasomatites developed in diopside-monticellite skarns below the lower exocontact of the Talnakh intrusion (the eastern part of the Komsomolsky mine). Thalhammerite, in pyrite-chalcopyrite-galena ores, occurs in association with cooperite, braggite, vysotskite, stibiopalladinite, telargpalite, sobolevskite, kotulskite, sopcheite, insizwaite, kravtsovite, vymazalováite, Au-Ag alloys, and Ag-bearing sulphides, selenides, sulphoselenides, and tellurosulphoselenides. The mineral was also observed in vein-disseminated millerite-bornite-chalcopyrite ore from the Talnakh and Oktyabrsk deposits of the Noril'sk region [3]. The host rocks of millerite-bornite-chalcopyrite ore are pyroxene-hornfels at the lower exocontact of the Kharaelakh intrusion (the western part of the Komsomolsky mine). In millerite-bornite-chalcopyrite ore, thalhammerite occurs in association with kotulskite, telargpalite, laflammeite, and Au-Ag alloys.

The mineral likely formed under the same conditions as kravtsovite and vymazalováite, with decreasing temperature [3], most likely below $400{ }^{\circ} \mathrm{C}$. Thalhammerite was also observed, in intergrowths with sobolevskite, in PGE ores from the Fedorov-Pana Layered Intrusive Complex, Russia (V.V. Subbotin-per. communication). Furthermore, the occurrence of unknown phases corresponding to $\mathrm{Pb}$ - and Tl-analogues of thalhammerite from the Fedorov-Pana Layered Intrusive Complex has been reported [4].

Both the mineral and name were approved by the Commission on New Minerals, Nomenclature and Classification of the International Mineralogical Association (IMA No 2017-111). The mineral name is for Dr. Oskar Thalhammer (b. 1956) Associate Professor at the University of Leoben, Austria for his contributions to the ore mineralogy and mineral deposits of platinum group elements. The type specimen is deposited at the Department of Earth Sciences of the Natural History Museum, London, UK, catalogue no. BM 2016, 150.

\section{Appearance, and Physical and Optical Properties}

Thalhammerite forms very small inclusions (from a few $\mu \mathrm{m}$ up to about 40-50 $\mu \mathrm{m}$ ) in galena, chalcopyrite (Figure 1), and also in bornite.

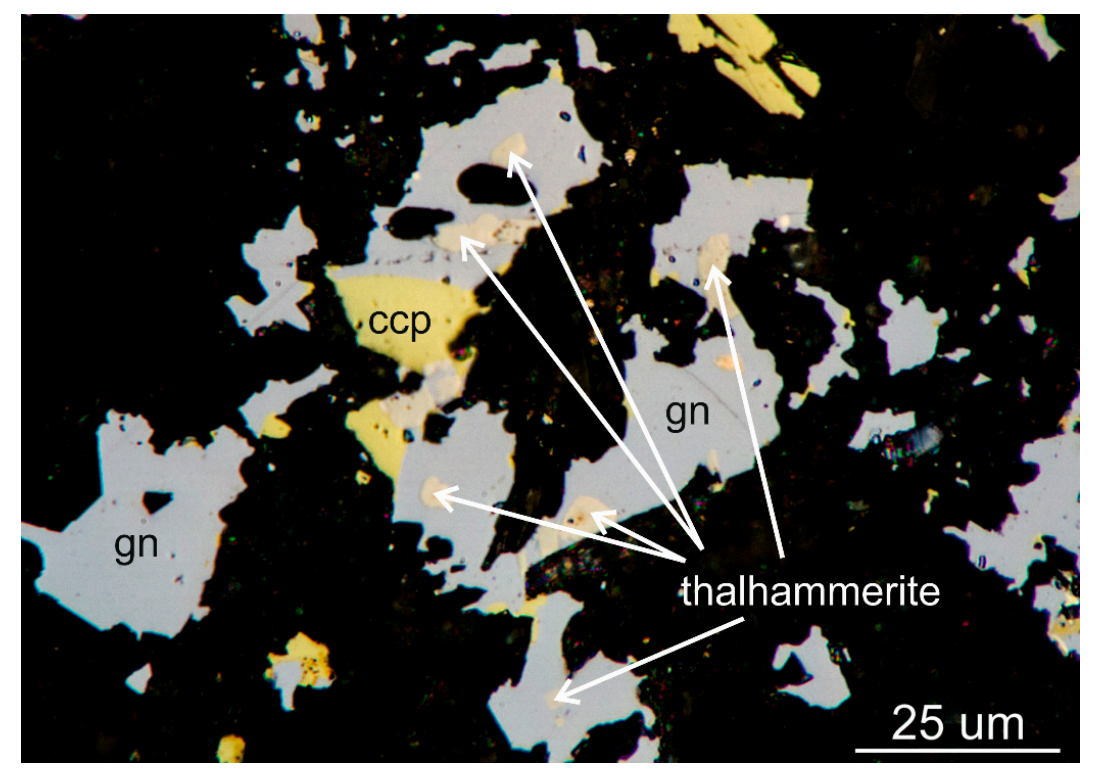

(a)

Figure 1. Cont. 


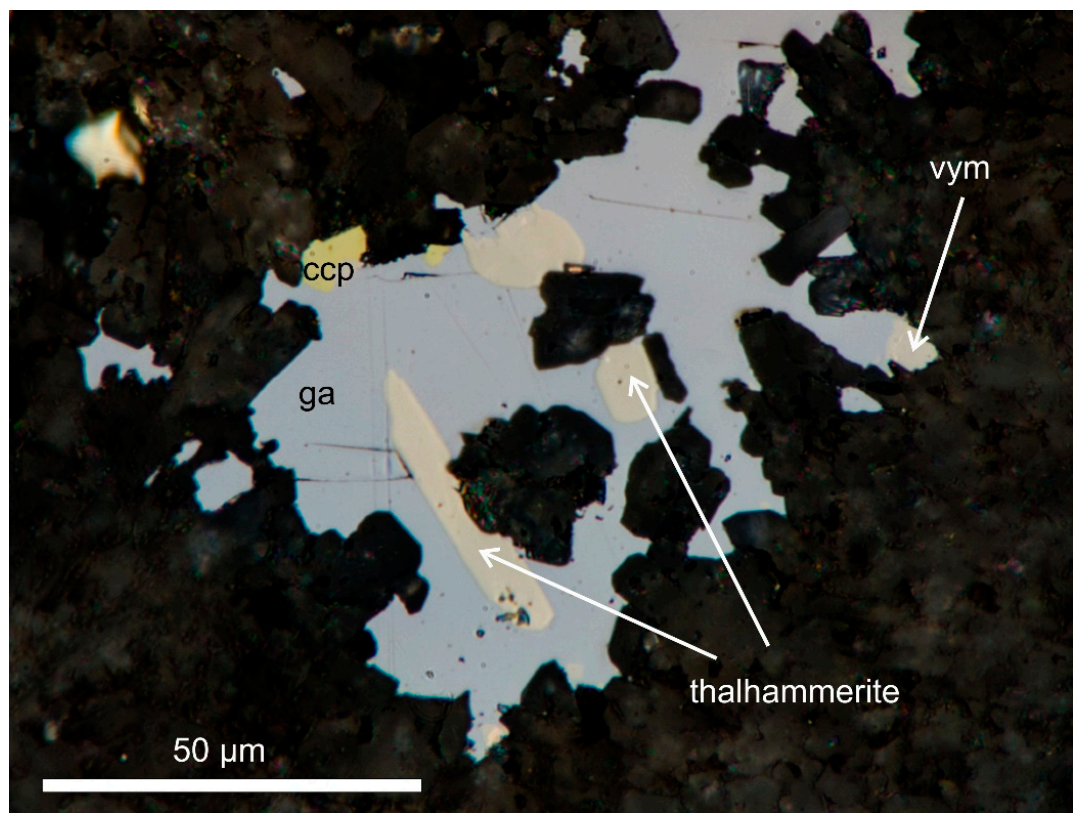

(b)

Figure 1. Digital image in reflected plane polarized light showing inclusions of thalhammerite in galena (gn) in association with (a) chalcopyrite (ccp) and (b) vymazalováite (vym).

The mineral occurs in aggregates (100-200 $\mu \mathrm{m}$ in size) formed by intergrowths of telargpalite, braggite, vysotskite, sopcheite, stibiopalladinite, sobolevskite, moncheite, kotulskite, malyshevite, insizwaite, acanthite, aurian silver, kravtsovite, and vymazalováite in association with galena, chalcopyrite, bornite, millerite, and pyrite.

Thalhammerite is opaque with a metallic lustre. The mineral is brittle. The density calculated on the basis of the empirical formula is $9.72 \mathrm{~g} / \mathrm{cm}^{3}$. In plane-polarized light, thalhammerite is light yellow with weak bireflectance, weak pleochroism, in shades of slightly yellowish brown and weak anisotropy. It exhibits no internal reflections.

Reflectance measurements were made in air relative to a WTiC standard on both natural and synthetic thalhammerite using a J and M TIDAS diode array spectrometer attached to a Zeiss Axiotron microscope. The results are tabulated (Table 1) and illustrated in Figure 2.

Table 1. Reflectance data for natural and synthetic thalhammerite.

\begin{tabular}{ccccc}
\hline \multirow{2}{*}{$\boldsymbol{\lambda}(\mathbf{n m})$} & \multicolumn{2}{c}{ Natural } & \multicolumn{2}{c}{ Synthetic } \\
\cline { 2 - 5 } & $\mathbf{R}_{\mathbf{1}} \mathbf{( \% )}$ & $\mathbf{R}_{\mathbf{2}} \mathbf{( \% )}$ & $\mathbf{R}_{\mathbf{1}} \mathbf{( \% )}$ & $\mathbf{R}_{\mathbf{2}} \mathbf{( \% )}$ \\
\hline 400 & 40.0 & 41.2 & 40.6 & 42.1 \\
420 & 40.6 & 41.8 & 41.3 & 42.6 \\
440 & 41.1 & 42.3 & 42.0 & 43.2 \\
460 & 41.7 & 42.8 & 42.6 & 43.9 \\
$\mathbf{4 7 0}$ & $\mathbf{4 1 . 9}$ & $\mathbf{4 3 . 0}$ & $\mathbf{4 2 . 9}$ & $\mathbf{4 4 . 3}$ \\
480 & 42.2 & 43.3 & 43.1 & 44.6 \\
500 & 42.7 & 43.9 & 43.8 & 45.3 \\
520 & 43.2 & 44.4 & 44.6 & 46.0 \\
540 & 43.7 & 44.9 & 45.3 & 46.6 \\
546 & 43.9 & $\mathbf{4 5 . 1}$ & $\mathbf{4 5 . 6}$ & 46.9 \\
560 & 44.2 & 45.4 & 45.9 & 47.2 \\
580 & 44.7 & 45.9 & 46.4 & 47.7 \\
589 & 44.9 & 46.1 & 46.7 & 47.9 \\
600 & 45.2 & 46.3 & 46.9 & 48.1 \\
620 & 45.6 & 46.8 & 47.3 & 48.5 \\
640 & 46.1 & 47.3 & 47.7 & 48.9 \\
\hline
\end{tabular}


Table 1. Cont

\begin{tabular}{ccccc}
\hline \multirow{2}{*}{$\lambda(\mathbf{n m})$} & \multicolumn{2}{c}{ Natural } & \multicolumn{2}{c}{ Synthetic } \\
\cline { 2 - 5 } & $\mathbf{R}_{\mathbf{1}} \mathbf{( \% )}$ & $\mathbf{R}_{\mathbf{2}} \mathbf{( \% )}$ & $\mathbf{R}_{\mathbf{1}} \mathbf{( \% )}$ & $\mathbf{R}_{\mathbf{2}} \mathbf{( \% )}$ \\
\hline $\mathbf{6 5 0}$ & $\mathbf{4 6 . 3}$ & $\mathbf{4 7 . 5}$ & $\mathbf{4 7 . 9}$ & $\mathbf{4 9 . 1}$ \\
$\mathbf{6 6 0}$ & 46.5 & 47.8 & 48.0 & 49.2 \\
680 & 47.0 & 48.3 & 48.3 & 49.5 \\
700 & 47.4 & 48.9 & 48.6 & 49.8 \\
\hline
\end{tabular}

Note. The values required by the Commission on Ore Mineralogy are given in bold.

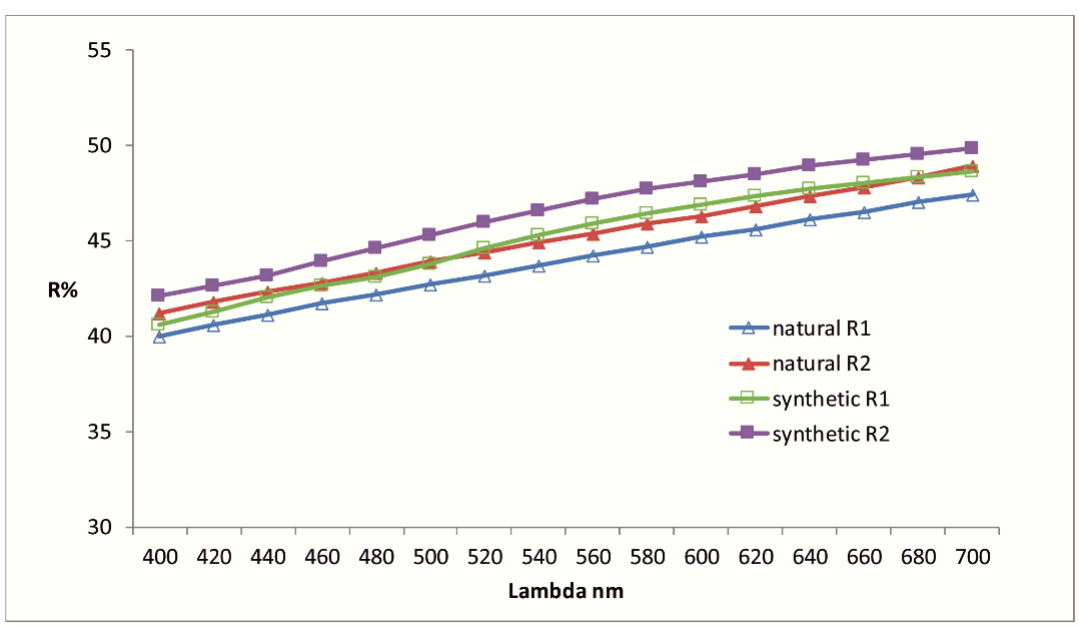

Figure 2. Reflectance data for thalhammerite compared to synthetic analogue, in air. The reflectance values $(\mathrm{R} \%)$ are plotted versus the wavelength $\lambda$ in $\mathrm{nm}$.

\section{Chemical Composition}

Electron probe micro-analyses (EPMA) on grains of thalhammerite were obtained using a WDA Inca Wave 500 (Oxford Instruments NanoAnalysis, High Wycombe, UK) installed on an SEM Lyra 3GM (Tescan), with analytical conditions of $20 \mathrm{kV}, 10 \mathrm{nA}$, and counting times of $30 \mathrm{~s}$ (on peak positions)/ $2 \times 15 \mathrm{~s}$ (background on the left and right positions). The spectra were collected on $\mathrm{PbM}_{\alpha}, \mathrm{BiM}_{\alpha}$, $\mathrm{PdL}_{\alpha}, \mathrm{AgL}_{\alpha}, \mathrm{SK}_{\alpha}$, and $\mathrm{SeL}_{\alpha}$ lines with standards of pure $\mathrm{Se}, \mathrm{Pd}, \mathrm{Ag}, \mathrm{Bi}$, synthetic $\mathrm{PbTe}$, and natural $\mathrm{FeS}_{2}$. Other elements were below the detection limit.

EPMA on synthetic thalhammerite were obtained using a CAMECA SX-100 electron probe microanalyzer in wavelength-dispersive mode with an electron beam focussed to 1-2 $\mu \mathrm{m}$.

Pure elements and $\mathrm{ZnS}$ were used as standards and the radiations measured were $\mathrm{BiM}_{\alpha} \mathrm{PdL}_{\alpha}$, $\mathrm{AgL}_{\alpha}$, and $\mathrm{SK}_{\alpha}$, with an accelerating voltage of $15 \mathrm{kV}$, and a beam current of $10 \mathrm{nA}$ measured on the Faraday cup.

EPMA compared with literature data are given in Table 2. The empirical formulae calculated on the basis of 17 apfu are $\mathrm{Pd}_{8.46} \mathrm{Ag}_{2.28}\left(\mathrm{Bi}_{1.82} \mathrm{~Pb}_{0.32}\right)_{\Sigma 2.14}\left(\mathrm{~S}_{4.10} \mathrm{Se}_{0.02}\right)_{\Sigma 4.12}$ for thalhammerite and $\mathrm{Pd}_{8.91} \mathrm{Ag}_{2.03} \mathrm{Bi}_{2.06} \mathrm{~S}_{4.00}$ for its synthetic analogue, with the ideal formulae $\mathrm{Pd}_{9} \mathrm{Ag}_{2} \mathrm{Bi}_{2} \mathrm{~S}_{4}$.

Table 2. Electron-microprobe analyses of natural and synthetic thalhammerite.

\begin{tabular}{|c|c|c|c|c|c|c|c|}
\hline wt $\%$ & $P d$ & Ag & $\mathrm{Pb}$ & $\mathrm{Bi}$ & $S$ & Se & Total \\
\hline \multicolumn{8}{|c|}{ Thalhammerite } \\
\hline \multirow{6}{*}{$\begin{array}{c}\text { average } \\
\text { 13/B-92 * }\end{array}$} & 52.80 & 14.57 & 2.60 & 22.56 & 7.75 & 0.07 & 100.35 \\
\hline & 53.40 & 14.29 & 3.05 & 22.09 & 7.62 & 0.03 & 100.47 \\
\hline & 51.64 & 14.25 & 6.12 & 21.98 & 7.70 & 0.19 & 101.87 \\
\hline & 52.61 & 14.37 & 3.92 & 22.21 & 7.69 & 0.10 & 100.90 \\
\hline & 53.85 & 12.51 & & 24.84 & 7.90 & & 99.1 \\
\hline & 52.77 & 12.27 & 1.77 & 24.29 & 7.45 & 0.57 & 99.12 \\
\hline
\end{tabular}


Table 2. Cont.

\begin{tabular}{|c|c|c|c|c|c|c|c|}
\hline wt $\%$ & Pd & Ag & $\mathbf{P b}$ & Bi & S & Se & Total \\
\hline \multicolumn{8}{|c|}{ Thalhammerite } \\
\hline \multirow[t]{3}{*}{$1 / \mathrm{K}-92$ * } & 53.85 & 12.8 & & 24.24 & 7.89 & & 99.01 \\
\hline & 52.77 & 11.83 & & 25.73 & 7.99 & & 99.53 \\
\hline & 54.08 & 12.21 & & 25.34 & 7.95 & & 101.21 \\
\hline \multicolumn{8}{|c|}{ Synthetic Sample } \\
\hline \multirow[t]{6}{*}{ Exp37 } & 54.18 & 13.69 & & 25.02 & 7.59 & & 100.48 \\
\hline & 54.74 & 12.91 & & 25.04 & 7.50 & & 100.19 \\
\hline & 54.66 & 12.46 & & 25.90 & 7.39 & & 100.42 \\
\hline & 56.14 & 12.01 & & 24.70 & 7.36 & & 100.21 \\
\hline & 55.78 & 12.67 & & 24.27 & 7.44 & & 100.16 \\
\hline & 55.10 & 12.75 & & 24.99 & 7.46 & & 100.29 \\
\hline average & 55.10 & 12.75 & & 24.99 & 7.46 & & 100.30 \\
\hline
\end{tabular}

\section{Synthetic Analogue}

The small size of thalhammerite embedded in galena (bornite) prevented its extraction and isolation in an amount sufficient for the relevant crystallographic and structural investigations. Therefore, these investigations were performed on the synthetic $\mathrm{Pd}_{9} \mathrm{Ag}_{2} \mathrm{Bi}_{2} \mathrm{~S}_{4}$.

The synthetic phase of $\mathrm{Pd}_{9} \mathrm{Ag}_{2} \mathrm{Bi}_{2} \mathrm{~S}_{4}$ was prepared in an evacuated and sealed silica-glass tube in a horizontal furnace in the Laboratory of Experimental Mineralogy of the Czech Geological Survey in Prague. To prevent loss of material to the vapour phase during the experiment, the free space in the tube was reduced by placing a closely-fitting silica glass rod against the charge.

The temperature was measured with Pt-PtRh thermocouples and is accurate to within $\pm 3{ }^{\circ} \mathrm{C}$. A charge of about $300 \mathrm{mg}$ was carefully weighed out from the native elements. We used, as starting chemicals, palladium (99.95\%), silver (99.999\%), bismuth (99.999\%), and sulphur (99.999\%). The starting mixture was sealed and annealed, quenched, and then ground in an agate mortar under acetone and reheated to $350^{\circ} \mathrm{C}$ for 134 days. The sample was quenched by dropping the capsule in cold water.

\section{X-ray Crystallography}

\subsection{Single-Crystal X-ray Diffraction}

A small fragment of synthetic $\mathrm{Pd}_{9} \mathrm{Ag}_{2} \mathrm{Bi}_{2} \mathrm{~S}_{4}$ was mounted on a glass fibre and examined using a Rigaku Super Nova single-crystal diffractometer with an Atlas S2 CCD detector utilizing MoK $\alpha$ radiation, provided by the microfocus $\mathrm{X}$-ray tube and monochromatized by primary mirror optics. The $\omega$ rotational scans were used for collection of three-dimensional intensity data. From a total of 3659 reflections, 221 were classified as unique observed with $I>3 \rho(I)$. Corrections for background, Lorentz effects and polarization were applied during data reduction with the CrysAlis software. Empirical absorption correction was performed using the same software yielding $R_{\text {int }}=0.034$. The crystal structure was solved with a charge-flipping method using the program Superflip [5] and subsequently refined by the full-matrix least-squares algorithm of JANA2006 program [6]. Because of the similarity of atomic number of Pd and $\mathrm{Ag}$ (46 and 47, respectively), it is nearly impossible to distinguish between these atoms from single-crystal (MoK $\alpha$ radiation) diffraction data. The refinement indicated five metallic positions, which one of them was assigned as Bi. The remaining metallic sites show multiplicities 2:8:8:4. Considering the empirical chemical composition $\operatorname{Pd}_{8.91} \mathrm{Ag}_{2.03} \mathrm{Bi}_{2.06} \mathrm{~S}_{4.00}$ $(Z=2)$ and coordination environment of the $4 e$ site, which was very different from the others (see structure description), the $4 e$ site was refined as Ag position. Next, refinement cycles included all anisotropic displacement parameters, which revealed too large a value for $\operatorname{Pd}(2)$ position $\left(U_{\text {eq }}(\operatorname{Pd} 2)=0.0146 \AA^{2}\right.$ cf. 0.0082 and $0.080 \AA^{2}$ for $\operatorname{Pd}(1)$ and $\operatorname{Pd}(3)$, respectively). Refinement of occupancy factors yielded 0.88 occupancy for the $\operatorname{Pd}(2)$ position; other positions were found to be fully occupied. Final refinement in the $14 / \mathrm{mmm}$ space group for 21 parameters converged smoothly to the 
$R=0.0310$ and $w R=0.0815$ for 221 observed reflections. Details of data collection, crystallographic data, and refinement are given in Table 3.

Table 3. Crystallographic data for the selected crystal of synthetic thalhammerite, $\mathrm{Pd}_{9} \mathrm{Ag}_{2} \mathrm{Bi}_{2} \mathrm{~S}_{4}$.

\begin{tabular}{|c|c|}
\hline \multicolumn{2}{|c|}{ Crystal Data } \\
\hline Chemical formula (idealized) & $\mathrm{Pd}_{9} \mathrm{Ag}_{2} \mathrm{Bi}_{2} \mathrm{~S}_{4}$ \\
\hline Space group & I4/mmm (No. 139) \\
\hline$a[\AA ̊]$ & $8.0266(2)$ \\
\hline$c[\AA]$ & $9.1531(2)$ \\
\hline$V\left[\AA^{3}\right]$ & $589.70(2)$ \\
\hline Z & 2 \\
\hline Crystal size (mm) & $0.034 \times 0.027 \times 0.013$ \\
\hline \multicolumn{2}{|c|}{ Data Collection } \\
\hline Diffractometer & SuperNova \\
\hline Temperature (K) & 293 \\
\hline Radiation & $\operatorname{MoK\alpha }(0.7107 \AA)$ \\
\hline Theta range $\left({ }^{\circ}\right)$ & $5.08-27.62$ \\
\hline Reflections collected & 3659 \\
\hline Independent reflections & 226 \\
\hline Unique observed reflections $[I>3(\sigma)]$ & 221 \\
\hline & $-10<h<10$ \\
\hline Index ranges & $-10<k<10$ \\
\hline & $-11<l<11$ \\
\hline Absorption correction method & Empirical \\
\hline \multicolumn{2}{|c|}{ Structure Refinement } \\
\hline Refinement method & Full matrix least-squares on $F^{2}$ \\
\hline Parameters/restrains/constrains & $21 / 0 / 0$ \\
\hline$R, \mathrm{w} R$ (obs) & $0.0310 / 0.0815$ \\
\hline$R, \mathrm{w} R($ all $)$ & $0.0318 / 0.0817$ \\
\hline Largest diff. peak and hole $\left(\mathrm{e}^{-} / \AA^{3}\right)$ & $1.20 /-5.20$ \\
\hline
\end{tabular}

Atom coordinates and displacement parameters are listed in Table 4. Table 5 shows selected bond lengths.

Table 4. Fractional coordinates and anisotropic displacement parameters $\left(\AA^{2}\right)$ for synthetic thalhammerite.

\begin{tabular}{ccccccc}
\hline Atom & $\mathbf{P d}(\mathbf{1})$ & $\mathbf{P d}(\mathbf{2}) *$ & $\mathbf{P d}(\mathbf{3})$ & $\mathbf{A g}$ & $\mathbf{B i}$ & $\mathbf{S}$ \\
\hline Wyckoff & $2 a$ & $8 f$ & $8 j$ & $4 e$ & $4 d$ & $8 h$ \\
Position & $1 / 2$ & $1 / 4$ & $1 / 2$ & $1 / 2$ & $1 / 2$ & $0.2081(4)$ \\
$x$ & $1 / 2$ & $1 / 4$ & $0.2027(2)$ & $1 / 2$ & 0 & $0.2081(4)$ \\
$y$ & $1 / 2$ & $1 / 4$ & 0 & $0.1810(2)$ & $1 / 4$ & 0 \\
$z$ & $0.0069(8)$ & $0.0104(8)$ & $0.0077(7)$ & $0.0098(6)$ & $0.0090(4)$ & $0.0071(12)$ \\
$U_{11}$ & $0.0069(8)$ & $0.0104(8)$ & $0.0097(7)$ & $0.0098(6)$ & $0.0090(4)$ & $0.0071(12)$ \\
$U_{22}$ & 0 & $0.0017(6)$ & $0.0077(7)$ & $0.0082(9)$ & $0.0079(6)$ & $0.012(2)$ \\
$U_{33}$ & $0.0109(13)$ & $0.0051(10)$ & 0 & 0 & 0 & $-0.0018(15)$ \\
$U_{12}$ & 0 & $0.0011(4)$ & 0 & 0 & 0 & 0 \\
$U_{13}$ & 0 & $0.0011(4)$ & 0 & 0 & 0 & 0 \\
$U_{23}$ & $0.0083(6)$ & $0.0086(5$ & $0.0084(4)$ & $0.0106(4)$ & $0.0086(3)$ & $0.0087(9)$ \\
$U_{\text {eq }}$ & & & & & &
\end{tabular}

* Refined with 0.88 occupancy.

Table 5. Selected bond distances $(\AA)$ in the thalhammerite crystal structure.

\begin{tabular}{cccccc}
\hline $\operatorname{Pd}(1)$ & $4 \times \mathrm{S}$ & $2.362(3)$ & $\mathrm{Ag}$ & $4 \times \operatorname{Pd}(3)$ & $2.905(1)$ \\
& $2 \times \mathrm{Ag}$ & $2.919(2)$ & & $4 \times \operatorname{Pd}(2)$ & $2.9073(4)$ \\
$\operatorname{Pd}(2)$ & $2 \times \mathrm{S}$ & $2.3372(7)$ & & & \\
& $2 \times \mathrm{Bi}$ & $2.8378(1)$ & $\mathrm{Bi} 1$ & $4 \times \operatorname{Pd}(3)$ & $2.808(1)$ \\
& $2 \times \mathrm{Ag}$ & $2.9073(4)$ & & $4 \times \operatorname{Pd}(2)$ & $2.8378(1)$ \\
& $4 \times \operatorname{Pd}(3)$ & $3.0670(2)$ & & & \\
\hline
\end{tabular}


Table 5. Cont.

\begin{tabular}{ccc}
\hline $\operatorname{Pd}(3)$ & $2 \times \mathrm{S}$ & $2.343(3)$ \\
& $2 \times \mathrm{Bi}$ & $2.8080(8)$ \\
& $2 \times \mathrm{Ag}$ & $2.905(2)$ \\
& $4 \times \operatorname{Pd}(2)$ & $3.0670(2)$ \\
\hline
\end{tabular}

It should be noted that the refined tetragonal structure model of thalhammerite is only a substructure. As was revealed by subsequent Rietveld refinement (see below), the powder X-ray diffraction pattern of synthetic thalhammerite shows at medium and high diffraction angles a few very weak unindexed peaks and very subtle peak splitting, which cannot be fitted using the tetragonal model. Attempts to refine the structure from single-crystal data in rhombic subgroups of $I 4 / \mathrm{mmm}$ (i.e., $F m m m$, Immm) led to negligible lowering of $R$-factors (e.g., from 0.0313 to 0.0293 ) with a rapid increase of the refined parameters and correlations between them. Refinements in monoclinic subgroups failed. Additionally, neither of these low-symmetry models describe all peak splitting observed in powder diffraction patterns of synthetic thalhammerite. Therefore, we proposed only the tetragonal average substructure of thalhammerite, leaving some aspects of the structure unclear.

\subsection{Powder X-ray Ddiffraction}

The powder XRD pattern of synthetic thalhammerite was collected in the Bragg-Brentano geometry on a Bruker D8 Advance diffractometer equipped with the LynxEye XE detector and $\mathrm{CuK \alpha}$ radiation. The data were collected in the range from $10^{\circ}$ to $100^{\circ} 2 \theta$ with a step size of $0.005^{\circ}$ $2 \theta$ and $2 \mathrm{~s}$ counting time per step. The structure model obtained from a single-crystal XRD study of synthetic thalhammerite was used as a starting structural model in the subsequent Rietveld refinement. The FullProf program [7] was used and the pseudo-Voigt function was used to generate the shape of the diffraction peaks. The refined parameters include those describing peak shape and width, peak asymmetry, unit-cell parameters, the occupancy parameter of the $\operatorname{Pd}(2)$ position, and six isotropic displacement parameters.

In total, 17 parameters were refined. No fractional coordinates were refined. The final cycles of Rietveld refinement converged to the agreement factors $R_{\mathrm{p}}=0.077$ and $R_{\mathrm{wp}}=0.115$. The refinement indicated $7 \mathrm{wt} \% \mathrm{Pd}_{3} \mathrm{Bi}_{2} \mathrm{~S}_{2}\left(I 2_{1} 3\right)$ impurity in the investigated sample.

Figure 3 depicts two details of final Rietveld plot showing weak, however discernible, peak splitting at middle and high diffraction angles of $2 \theta$ (i.e., above $50^{\circ}$ ). Attempts to index all observed diffractions in the powder pattern in the large and/or lower symmetry unit-cell remained unsuccessful and, therefore, the structure refinement was limited to the tetragonal substructure. Table 6 presents powder diffraction data for thalhammerite.
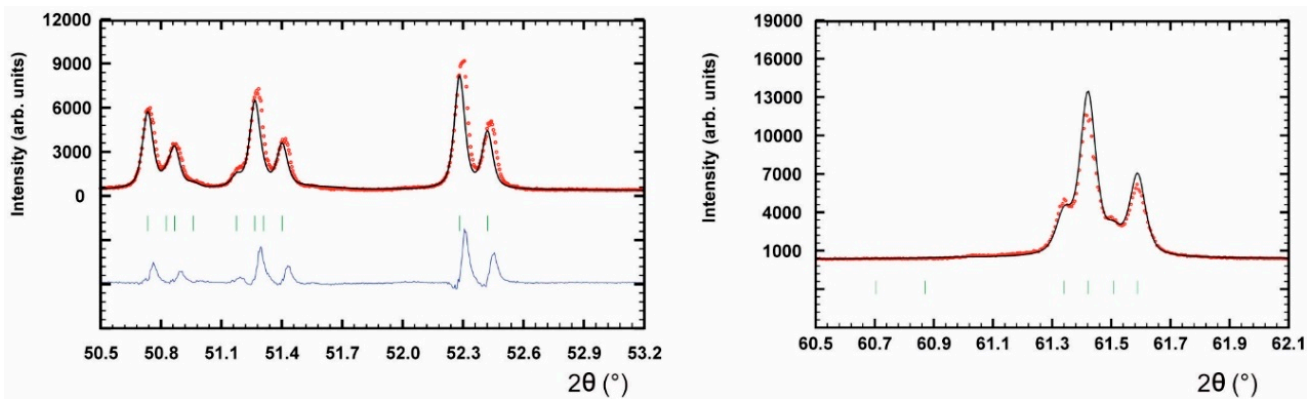

Figure 3. Details of the Rietveld profiles of synthetic thalhammerite showing the weak peak splitting, which cannot be fitted using the tetragonal cell. The observed (circles), calculated (solid), and difference profiles are shown. The vertical bars correspond to Bragg reflections. 


\section{Structure Description}

The tetragonal substructure of thalhammerite contains three $\mathrm{Pd}$, one $\mathrm{Ag}, \mathrm{Bi}$, and $\mathrm{S}$ sites, respectively. All sites, except the $\operatorname{Pd}(2)$ position, were found to be fully occupied. Its crystal structure is shown in Figure 4.

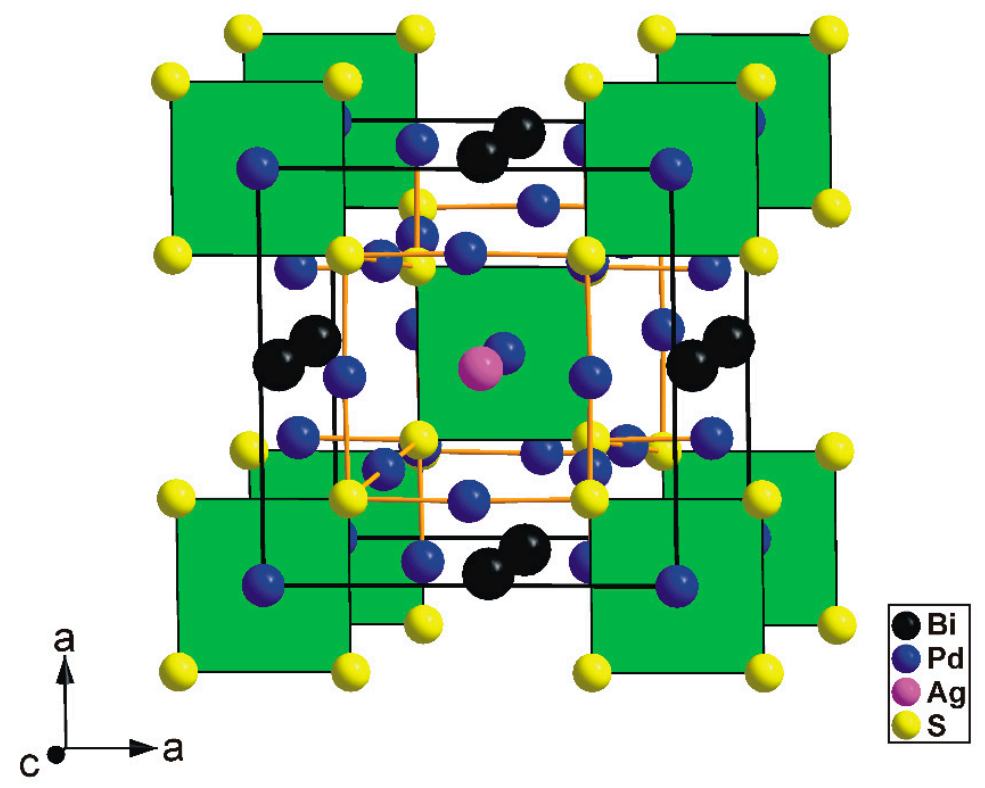

Figure 4. Crystal structure of thalhammerite showing the $\left[\mathrm{PdS}_{4}\right]$ squares and $\mathrm{Pd}-\mathrm{S}$ bonds. Unit-cell edges are highlighted. Details show the Rietveld profiles of synthetic thalhammerite showing the weak peak splitting, which cannot be fitted using the tetragonal cell.

\subsection{Coordination of Cations}

The $\operatorname{Pd}(1)$ position is in the centre of regular square of $S$ atoms with $\operatorname{Pd}(1)-S$ distances of 2.362(3) $\AA$. The coordination is perfectly planar. Similar coordination was observed in vysotskite, PdS [8], which shows similar Pd-S separation of $2.34 \AA$. Such coordination geometry is typical for low-spin $4 d^{8} \mathrm{Pd}^{2+}$ cation in normal sulfides with M:S ratio equal to or smaller to one [9]. The $\operatorname{Pd}(1)$ coordination is further completed by two Ag atoms at 2.919(2) A lying perpendicular to the [M(1) $\left.\mathrm{S}_{4}\right]$ squares.

The $\mathrm{Pd}(2)$ (refined to 0.88 occupancy of $\mathrm{Pd}$ ) and $\mathrm{Pd}(3)$ sites form complex polyhedron. Both $\mathrm{Pd}$ positions are coordinated by two $\mathrm{S}$ atoms at distances $2.3372(7)$ and 2.343(3) $\AA$, a value very close to the Pd-S distance of 2.334(4) $\AA$ observed for the zig-zag chains in the structure of kravtsovite, $\mathrm{PdAg}_{2} \mathrm{~S}$ [1]. Whereas the $\mathrm{S}-\mathrm{Pd}(2)-\mathrm{S}$ group is perfectly linear, the $\mathrm{S}-\mathrm{Pd}(3)-\mathrm{S}$ shows a bonding angle of $177.9(1)^{\circ}$. $\operatorname{Pd}(2)$ is further coordinated by two Bi (2.8378(1) $\AA$ ), two Ag (2.9073(4) $\AA$ ), and two $\operatorname{Pd}(3)(3.0670(2) \AA)$ atoms. $\operatorname{Pd}(3)$ also shows two Bi (2.8080(8) $\AA$ ), two $\operatorname{Ag}(2.905(2) \AA)$, and four $\operatorname{Pd}(3)$ (3.0670(2) ̊) short contacts.

$\mathrm{Ag}$ site is surrounded by nine Pd atoms (Figure 5) forming a mono-capped tetragonal antiprismatic coordination. The Ag-Pd distances are in the range of 2.905(1) $\AA$ to 2.919(2) $\AA$, comparable to those observed in lukkulaisvaaraite (Pd-Ag: 2.891(4)-3.037(4) $\AA$; [10], where Ag atoms display tetragonal antiprismatic coordination.

As is shown in Figure 5, the Bi atom is coordinated by eight Pd atoms to form a bi-capped trigonal prism with $\mathrm{Bi}-\mathrm{Pd}$ bond distances ranging from 2.808(1) to 2.8378(1) $\AA$, values slightly shorter than those observed in structure of monoclinic PdBi (2.84-2.95) $\AA$; [11]. There are no short $(<3.5 \AA)$ Bi-S contacts in the thalhammerite crystal structure. This contrasts with the environment of $\mathrm{Bi}$ in structure of chemically-related vymazalováite, $\mathrm{Pd}_{3} \mathrm{Bi}_{2} \mathrm{~S}_{2}$ [2,12], where $\mathrm{Bi}$ atoms show one additional $\mathrm{S}$ contact at 3.22(3) ̊. 
Table 6. X-ray powder diffraction data of thalhammerite $(\mathrm{CuK} \alpha$ radiation, Bruker D8 Advance, Bragg-Brentano geometry). Only reflections with $I_{(\mathrm{obs})} \geq 1$ are listed.

\begin{tabular}{cccccc}
\hline$I_{\text {(obs) }}$ & $\boldsymbol{h}$ & $\boldsymbol{k}$ & $\boldsymbol{l}$ & $\boldsymbol{d}_{\text {(meas) }}$ & $\boldsymbol{d}_{\text {(calc) }}$ \\
\hline 11 & 1 & 0 & 1 & 6.0364 & 6.0338 \\
11 & 1 & 1 & 0 & 5.6790 & 5.6767 \\
13 & 0 & 0 & 2 & 4.5752 & 4.5736 \\
8 & 2 & 0 & 0 & 4.0155 & 4.0140 \\
18 & 1 & 1 & 2 & 3.5620 & 3.5615 \\
24 & 2 & 1 & 1 & 3.3428 & 3.3420 \\
2 & 2 & 0 & 2 & 3.0181 & 3.0169 \\
9 & 1 & 0 & 3 & 2.8510 & 2.8504 \\
46 & 2 & 2 & 0 & 2.8393 & 2.8383 \\
21 & 3 & 0 & 1 & 2.5685 & 2.5684 \\
100 & 2 & 2 & 2 & 2.4122 & 2.4117 \\
61 & 1 & 2 & 3 & 2.3245 & 2.3241 \\
48 & 0 & 0 & 4 & 2.2873 & 2.2868 \\
29 & 1 & 3 & 2 & 2.2201 & 2.2197 \\
2 & 2 & 3 & 1 & 2.1637 & 2.1634 \\
17 & 1 & 1 & 4 & 2.1213 & 2.1212 \\
40 & 4 & 0 & 0 & 2.0072 & 2.0070 \\
3 & 3 & 3 & 0 & 1.8923 & 1.8922 \\
8 & 4 & 0 & 2 & 1.8377 & 1.8378 \\
15 & 2 & 3 & 3 & 1.7981 & 1.7982 \\
18 & 2 & 2 & 4 & 1.7805 & 1.7807 \\
23 & 3 & 3 & 2 & 1.7481 & 1.7485 \\
4 & 1 & 3 & 4 & 1.6991 & 1.6991 \\
2 & 4 & 2 & 2 & 1.6711 & 1.6710 \\
5 & 1 & 4 & 3 & 1.6413 & 1.6410 \\
1 & 2 & 1 & 5 & 1.6299 & 1.6300 \\
4 & 4 & 3 & 1 & 1.5814 & 1.5814 \\
1 & 5 & 1 & 0 & 1.5743 & 1.5744 \\
8 & 0 & 3 & 5 & 1.5102 & 1.5103 \\
30 & 4 & 0 & 4 & 1.5085 & 1.5085 \\
9 & 1 & 1 & 6 & 1.4723 & 1.4724 \\
13 & 4 & 4 & 0 & 1.4193 & 1.4192 \\
7 & 4 & 4 & 2 & 1.3554 & 1.3554 \\
12 & 2 & 2 & 6 & 1.3431 & 1.3431 \\
9 & 2 & 5 & 3 & 1.3395 & 1.3393 \\
1 & 3 & 5 & 2 & 1.3185 & 1.3184 \\
19 & 3 & 1 & 6 & 1.3070 & 1.3070 \\
7 & 1 & 5 & 4 & 1.2969 & 1.2968 \\
9 & 6 & 2 & 0 & 1.2694 & 1.2693 \\
3 & 1 & 2 & 7 & 1.2279 & 1.2279 \\
18 & 6 & 2 & 2 & 1.2231 & 1.2231 \\
1 & 1 & 6 & 3 & 1.2113 & 1.2112 \\
10 & 4 & 4 & 4 & 1.2059 & 1.2058 \\
11 & 3 & 3 & 6 & 1.1872 & 1.1871 \\
\hline & & & & & \\
\hline
\end{tabular}
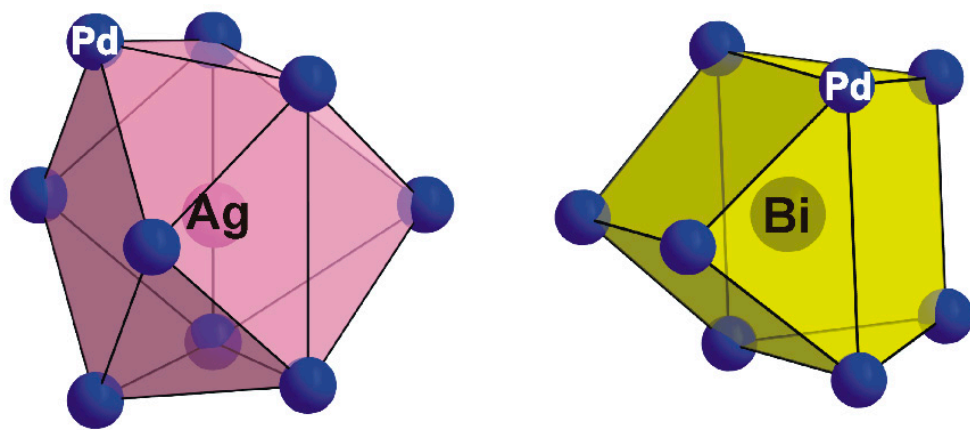

Figure 5. Coordination polyhedra of Ag (mono-capped tetragonal antiprism) and Bi (bi-capped trigonal prism) in the thalhammerite structure. 


\subsection{Modular Description}

The thalhamerite crystal structure forms a three-dimensional framework. It contains features typical for intermetallic compounds (e.g., complex crystallochemical environment of metals) and, therefore, cannot be presented using a traditional cation-based coordination polyhedra approach.

Alternatively, the structure of thalhammerite can be conveniently described as an arrangement of two types of building blocks (cuboids) having common $S$ atoms at the corners (Figure 6).

The first block (green in Figure 6) contains the $\left[\mathrm{PdS}_{4}\right]$ squares forming one face of the block and Ag atoms in its centre. Pd atoms are approximately located to the midpoints of the longer S-S edges. The second block (orange in Figure 6) contains Bi atoms in its centre. By analogy with the first block, the Pd atoms are located to the midpoints of the longer S-S edges. In the thalhammerite structure, two types of block alternate in a chess-boar fashion within the (001) plane and form chains along the $c$ axis (Figure 6). It should be mentioned that, neglecting the $\mathrm{Ag}$ and $\mathrm{Bi}$ atoms, the packing of the green blocks automatically generates their duals, and the orange block, vice versa.

(a)

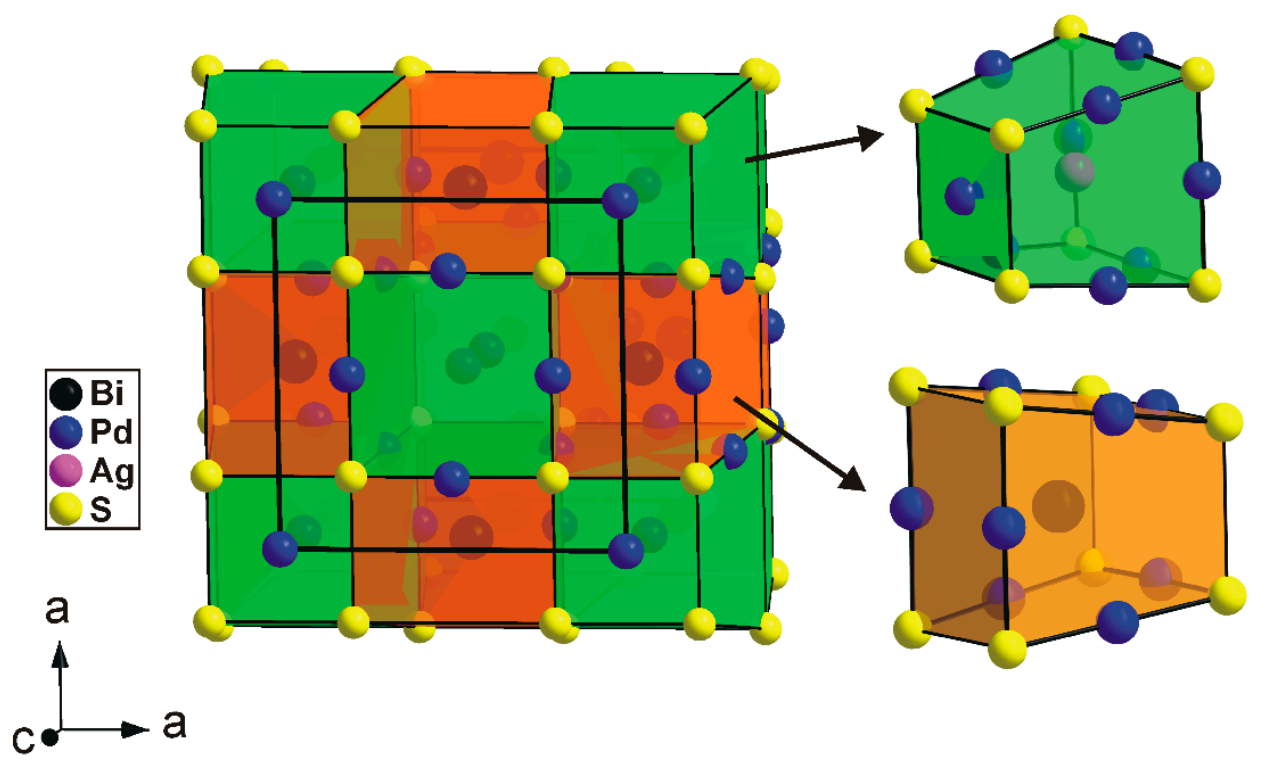

Figure 6. (a) Arrangement of two types of building blocks in the thalhammerite structure. (b) Detailed view showing the block containing Ag (green) and Bi (orange) atoms.

\subsection{Relation to Other Minerals}

The thalhammerite structure represents a unique structure type, and no exact structural analogue is hitherto known. It is worth noting that its structure merges structure motives typical for polar chalcogenides and intermetallic compounds. The $\left[\mathrm{Pd}(1) \mathrm{S}_{4}\right]$ square-planar coordination is a hallmark of Pd-bearing sulfides with an M:S ratio equal to, or slightly smaller than, one. Contrary to that, (almost) linear coordination of Pd by two S atoms and number of further metal-metal contacts resulting in complex coordination geometry, can be observed in sulphides with intermetallic behaviour (e.g., kravtsovite PdAg 2 S, Vymazalová et al., 2017 [1]).

Another chemically-related mineral, coldwellite, $\mathrm{Pd}_{3} \mathrm{Ag}_{2} \mathrm{~S}$ (McDonald et al., 2015 [13]), adopts a cubic $\beta$-Mn-like structure and, hence, differs substantially from that of thalhammerite.

\section{Proof of Identity of Natural and Synthetic Thalhammerite}

The structural identity between the synthetic $\mathrm{Pd}_{9} \mathrm{Ag}_{2} \mathrm{Bi}_{2} \mathrm{~S}_{4}$ and the natural material was confirmed by electron back-scattering diffraction (EBSD) and Raman spectroscopy. 


\subsection{Electron Back-Scattering Diffraction}

The structural identity between the natural material and the synthetic $\mathrm{Pd}_{9} \mathrm{Ag}_{2} \mathrm{Bi}_{2} \mathrm{~S}_{4}$ was confirmed by EBSD. A TESCAN Lyra 3GM field emission scanning electron microscope combined with EBSD system (Oxford Instruments AztecHKL system with NordlysNano EBSD camera) was used for the measurements. The surface of natural sample was prepared for investigation by broad beam argon ion milling using Gatan PECS II system operated at $1 \mathrm{kV}$. The solid angles calculated from the patterns were compared with our structural model for $\mathrm{Pd}_{9} \mathrm{Ag}_{2} \mathrm{Bi}_{2} \mathrm{~S}_{4}$ synthetic phase match containing 12 reflectors to index the patters. The EBSD patterns (also known as Kikuchi patterns) obtained from the natural material (>50 measurements on different spots on natural thalhammerite grains) were found to match the patterns generated from our structural model for $\mathrm{Pd}_{9} \mathrm{Ag}_{2} \mathrm{Bi}_{2} \mathrm{~S}_{4}$ synthetic phase, Figure 7 .
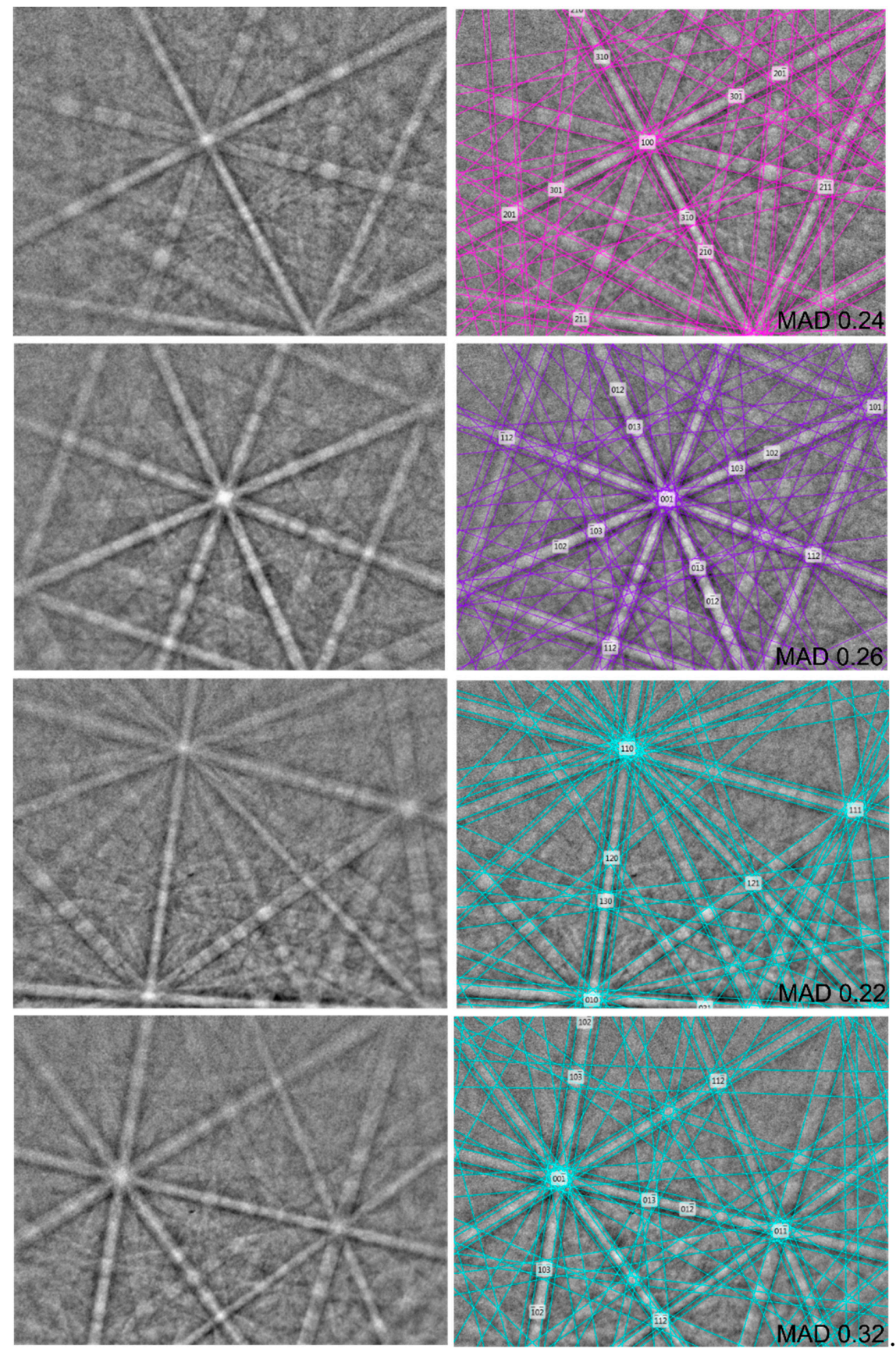

Figure 7. EBSD image of natural thalhammerite; in the right pane, the Kikuchi bands are indexed. 
The values of the mean angular deviation (MAD, i.e., goodness of fit of the solution) between the calculated and measured Kikuchi bands range between $0.22^{\circ}$ and $0.48^{\circ}$. These values reveal a very good match; as long as values of mean angular deviation are less than $1^{\circ}$, they are considered as indicators of an acceptable fit (HKL Technology, 2004).

\subsection{Raman Spectroscopy}

The Raman spectroscopy technique was applied to verify the structural identity between the synthetic $\mathrm{Pd}_{9} \mathrm{Ag}_{2} \mathrm{Bi}_{2} \mathrm{~S}_{4}$ and the natural material (Figure 8).

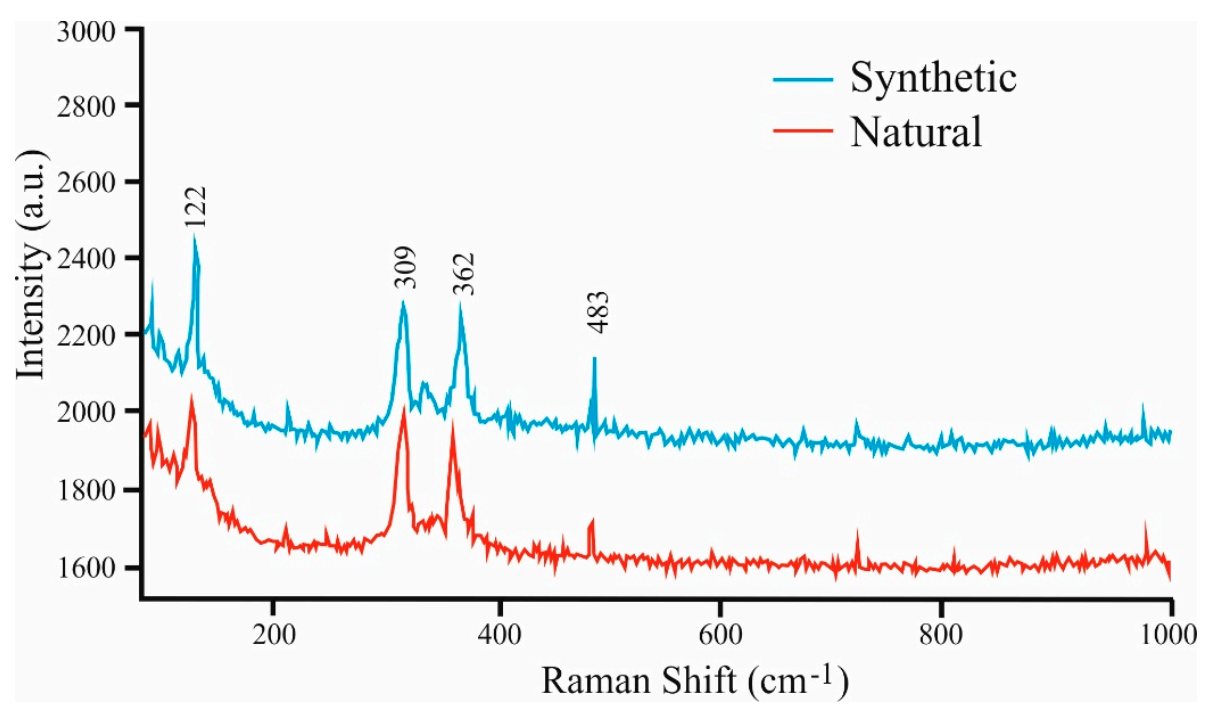

Figure 8. Comparison of Raman spectra in the synthetic $\mathrm{Pd}_{9} \mathrm{Ag}_{2} \mathrm{Bi}_{2} \mathrm{~S}_{4}$ and in the natural material.

Raman spectra were obtained using a LABRAM (ISA Jobin Yvon) instrument installed at the University of Leoben, Austria. A frequency-doubled $100 \mathrm{~mW}$ Nd:YAG laser with an excitation of a wavelength of $\lambda=532.6 \mathrm{~nm}$ was used. The obtained Raman spectra of natural and synthetic $\mathrm{Pd}_{9} \mathrm{Ag}_{2} \mathrm{Bi}_{2} \mathrm{~S}_{4}$ show four discernible absorption bands at the following values: 122, 309, 362, and $483 \mathrm{~cm}^{-1}$ (see Figure 8 ).

The EBSD study, Raman spectra, chemical identity and optical properties confirmed the identity of the natural and synthetic materials and thereby legitimise the use of the synthetic phase for the complete characterization of thalhammerite.

Author Contributions: All the authors (A.V., F.L., S.F.S., V.V.K., C.J.S., J.P., F.Z., G.G. and R.B.) discussed the obtained results, evaluated the data and wrote the article together. A.V. designed the article and conceived experiments; S.F.S. provided the samples and geological background; F.L., V.V.K., J.P. obtained the crystallographic data; C.J.S. provided optical properties; F.Z., G.G. and R.B. studied thalhammerite by Raman and evaluated the chemical data. All the authors revised and edited the manuscript.

Funding: The work was supported by the Grant Agency of the Czech Republic (project no. 18-15390S to A.V.), through an internal project 331400 from the Czech Geological Survey, the Russian Foundation for Basic Research (project RFBR 18-05-70073), and C.J.S. acknowledges Natural Environment Research Council, grant NE/M010848/1, Tellurium and Selenium Cycling and Supply.

Acknowledgments: The authors acknowledge Ulf Hålenius, Chairman of the CNMNC and its members for helpful comments on the submitted data. The authors are grateful to Zuzana Korbelová (Institute of Geology AS CR, v.v.i.) for carrying out the electron microprobe analyses. We thank two anonymous reviewers and the Editorial Board members, for their comments and improvements.

Conflicts of Interest: The authors declare no conflict of interest. 


\section{References}

1. Vymazalová, A.; Laufek, F.; Sluzhenikin, S.F.; Stanley, C.J.; Kozlov, V.V.; Chareev, D.A.; Lukashova, M.L. Kravtsovite, $\mathrm{PdAg}_{2} \mathrm{~S}$, a new mineral from Norilsk-Talnakh deposit, Russia. Eur. J. Mineral. 2017, 29, 597-602. [CrossRef]

2. Sluzhenikin, S.F.; Kozlov, V.V.; Stanley, C.J.; Lukashova, M.I.; Dicks, K. Vymazalováite, $\operatorname{Pd}_{3} \mathrm{Bi}_{2} \mathrm{~S}_{2}$, a new mineral from Norilsk -Talnakh deposit, Krasnoyarskiy region, Russia. Mineral. Mag. 2018, 82, 367-373. [CrossRef]

3. Sluzhenikin, S.F.; Mokhov, A.V. Gold and silver in PGE-Cu-Ni and PGE ores of the Norilsk deposit, Russia. Mineral. Depos. 2015, 50, 465-492. [CrossRef]

4. Subbotin, V.V.; Gabov, D.A.; Korchagin, A.U.; Savchenko, E.E. Gold and Silver in the Composition of PGE Ores of the Fedorov-Pana Layered Intrusive Complex. Her. Kola Sci. Cent. RAS 2017, 1, 53-65. (In Russian)

5. Palatinus, L.; Chapuis, G. SUPERFLIP-A computer program for the solution of crystal structures by charge flipping in arbitrary dimensions. J. Appl. Crystallogr. 2007, 41, 786-790. [CrossRef]

6. Petříček, V.; Dušek, M.; Palatinus, L. Crystallographic Computing System JANA2006: General features. Z. Kristallogr. 2014, 229, 345-352. [CrossRef]

7. Rodríguez-Carvajal, J. Full Prof. $2 k$ Rietveld Profile Matching E Integrated Intensities Refinement of X-ray and/or Neutron Data (Powder and/or Single-Crystal); Laboratoire Léon Brillouin, Centre d'Etudes de Saclay: Gif-sur-Yvette, France, 2006.

8. Brese, N.E.; Squattrito, P.J.; Ibers, J.A. Reinvestigation of the structure PdS. Acta Crystallogr. Sect. C 1985, C41, 1829-1830. [CrossRef]

9. Dubost, V.; Balić-Žunić, T.; Makovicky, E. The crystal structure of $\mathrm{Ni}_{9.54} \mathrm{Pd}_{7.46} \mathrm{~S}_{15}$. Can. Mineral. 2007, 45, 847-855. [CrossRef]

10. Vymazalová, A.; Grokhovskaya, T.L.; Laufek, F.; Rassulov, V.A. Lukkulaisvaaraite, $\operatorname{Pd}_{14} \mathrm{Ag}_{2} \mathrm{Te}_{9}$, a new mineral from Lukkulaisvaara intrusion, northern Russian Karelia, Russia. Mineral. Mag. 2014, 78, 1743-1754. [CrossRef]

11. Bhatt, Y.C.; Schubert, K. Kristallstruktur von PdBi.r. J. Less Common Met. 1979, 64, 17-24. [CrossRef]

12. Weihrich, R.; Matar, S.F.; Eyert, V.; Rau, F.; Zabel, M.; Andratschke, M.; Anusca, I.; Bernert, T. Structure, ordering and bonding of half antiperovskites $\mathrm{PbNi}_{3 / 2} \mathrm{~S}$ and $\mathrm{BiNi}_{3 / 2} \mathrm{~S}$. Prog. Solid State Chem. 2007, 35, 309-327. [CrossRef]

13. McDonald, A.M.; Cabri, L.J.; Stanley, C.J.; Good, D.J.; Redpath, J.; Spratt, J. Coldwellite, $\operatorname{Pd}_{3} \mathrm{Ag}_{2} \mathrm{~S}$, a new mineral species from the Marathon deposit, Coldwell Complex, Ontario, Canada. Can. Mineral. 2015, 53, 845-857. [CrossRef]

(C) 2018 by the authors. Licensee MDPI, Basel, Switzerland. This article is an open access article distributed under the terms and conditions of the Creative Commons Attribution (CC BY) license (http://creativecommons.org/licenses/by/4.0/). 